International Journal of Linguistics, Literature and Translation (IJLLT)

ISSN: 2617-0299 (Online); ISSN: 2708-0099 (Print)

DOI: 10.32996/ijllt

Website: https://al-kindipublisher.com/index.php/ijllt/index

IJLLT

\title{
Creativity in The Use of Translation Microstrategies By Translation Students at the University of Bahrain
}

Dr. Nuri Ageli

Associate professor, University of Bahrain, Bahrain

Corresponding Author: Dr. Nuri Ageli, E-mail: nageli@uob.edu.bh

ARTICLE INFORMATION ABSTRACT

Received: September 02, 2020

Accepted: October 18, 2020

Volume: 3

Issue: 10

DOI: $10.32996 /$ ijllt.2020.3.10.2

\section{KEYWORDS}

Microstrategies, macrostrategies, creativity, translation, equivalence, source text, target text
This study aims to examine University of Bahrain graduating translation students' use of creative microstrategies in rendering into English a news text and compare it with the translation of a Bahrain News Agency professional translator. The study seeks to identify the students' creative microstrategies based on the classification proposed by Anne Schjoldager's' (2008) model of macrostrategies. The participants were 15 English language students with a minor in translation who were expected to graduate in the semester during which the study was conducted. They were required to translate a news text from Arabic to English in order to reveal the creative microstrategies used and then their performance was compared with that done by a professional translator employed by Bahrain News Agency (BNA)and published on its official website. The findings of the study have shown that translation students are inclined to focus more on the syntactic microstrategies rather than on the semantic and pragmatic ones when processing and rendering the source text into the target language. Unlike the professional translator, students' lack of negotiation with and deeper analysis of the text has deprived their performance to a certain extent from the creativity required in translation and rendered it into a mechanical exercise.

\section{Introduction}

Translation can be viewed from the perspectives of product and process. As a product, the focus is on the translation itself i.e the source and the target texts with the aim of evaluating the translated text and providing feedback to improve its quality. As a process, the focus is on the translator and how he/she interacts with the text in order to achieve a good product i.e. good translation which, in turn, has practical and pedagogical implications. With that being said, it becomes clear that there is mutual influence between the product and the process in translation. A quality product is inevitably a result of a well thought out process based on sound decisions by the translator. This will lead eventually to producing good translation that is an accurate and adequate reflection of the source text. This paper will be dealing with the process of translation in terms of the creative microstrategies used by graduating students in translating a local news text and then comparing it with the translation microstrategies employed by a professional translator.

To start with, it is important to shed some light on the term strategy as used in the literature on translation. The term was referred to by Nida (1964) as a procedure and divided it into technical and organizational types. From a more communicative approach, he further uses the term 'techniques of adjustment' to refer to translation processes, the aim of which is to 'produce correct equivalents' (p. 23). According to Nida, the function of these techniques of adjustment is to: (1) allow for adjusting the form the message to the structural requirements of the receptor language; (2) produce semantically equivalent structures; (3) provide stylistically appropriate equivalents; and (4) allow for a communicative equivalence. Loescher (1991, $p$. 8) defines translation strategy as "a potentially conscious procedure for solving a problem faced in translating a text, or any segment of it. Venuti (1998, p.240) talking about developing a method points out that translation "involves the basic tasks of choosing the foreign text to be translated and developing a method to translate it." In Approaches to Translation, Newmark (1988, p.81), on the other hand, distinguished between method and procedure stating that "while translation methods relate

\footnotetext{
K C AL-KINDI CENTER R D FOR RESEARCH AND Your gatewoy to world-class research
}

Published by Al-KindiCenter for Research and Development. Copyright (c) the author(s). This is an open access article under CC BY license (https://creativecommons.org/licenses/by/4.0/) 
to the whole text, translation procedures are used for sentences and the small units of language". The term strategy is also used synonymously with terms such "procedure," "technique," "method," "tactic," "approach," (Sun, 2012). Yet, all these terms overlap in their definitions. What is common among them is that they are all represent a conscious, goal-oriented and problem-solving decision. In this paper the term strategy is adopted in line with the definition of Krings $(1986, p .18)$ in which he would consider translation strategies as conscious plans for solving concrete translation problems in the framework of a concrete translation task. Given that all the various terms are overlapping in one way or another, the term strategy will be used in this research as a general or an umbrella term that encompasses all of the above to serve in the words of De Beaugrande (1978, p.14) "as tools to tackle (approximately, not definitively) the possible problems that could emerge during translation".

As far as types are concerned, translation strategies can be subcategorized into macrostrategies and microstrategies:

\subsection{Macrostrategies}

Macrostrategies, which are also called "global strategies by Bell (1998, p.188), Chesterman (1997, p.87) and Jaaskelainen $(2005$, p.16), among others, are the strategies that deal with the text as a whole and not as segments. "They are the translator's overall plan" and "practically put translation into a continuum with a spectrum of SL-orientation and a spectrum of TL- orientation" Jensen (2009, p.29). The translator will have to decide whether to focus on the form and content of the source text and, as a result, follow a semantic approach or, conversely, focus on the effect of the source text and, consequently, adopt a communicative approach (Schjoldager 2008, pp. 67-70). These two approaches are defined as ST oriented macrostrategy and a TT oriented macrostrategy. Jensen (2009) says that it is possible for the translator to plan a translation strategy on the macro level, which will enable him to fulfil the skopos.

Macrostrategies have been classified by different scholars in a dichotomy of binary division. Some of the famous examples are:

Table 1: Macrostrategies

\begin{tabular}{lll}
\hline Translation Scholar & Source language oriented & Target language oriented \\
\hline Jean-Paul Vinay and Jean Darbelnet (1958/2000) & Direct translation & Oblique translation \\
\hline Eugene Nida (1964/2000) & Formal equivalence & Dynamic equivalence \\
\hline Peter Newmark (1977/1989) & Semantic translation & Communicative translation \\
\hline Gideon Toury (1995) & $\begin{array}{l}\text { Adequate translation } \\
\text { (subject to ST and culture) }\end{array}$ & $\begin{array}{l}\text { Acceptable translation } \\
\text { ( subject to TT \& culture) }\end{array}$ \\
\hline Laurence Venuti (1995) & Foreignising translation & Domesticating translation \\
\hline Christiane Nord (1997) & Documentary translation & Instrumental translation \\
\hline Julianne House (1997) & Overt & Covert \\
\hline
\end{tabular}

Source : Schjoldager cited in Jensen (2009, p.30) - with modification

\subsection{Microstrategies}

Whereas macrostrategies deal with the text as a whole, microstrategies, also called local strategies (Chesterman, 1997), work at a lower and more specific level and affect the smaller segments. Vinay and Darbelnet (1995) propose two methods for translators i.e. direct translation, which includes borrowing, calque and literal translation, and oblique translation, which is used when it becomes impossible to employ direct translation. It includes the subcategories of transposition, modulation, equivalence, and adaptation.

Baker (1992, pp.26-42) has a classification of eight strategies that translators can use in their translation when they come across translation problems. They are as follows:

1. Translation by a more general word.

2. Translation by a more neutral/ less expressive word.

3. Translation by cultural substitution.

4. Translation using a loan word or loan word plus explanation.

5. Translation by paraphrase using a related word

6. Translation by paraphrase using unrelated words

7. Translation by omission

8. Translation by illustration 
For the purpose of this study, the microstrategies proposed by Schjoldager $(2008$, p.89) are adopted with some modification. The reason for this choice is explained by Yang $(2010$, p.32) in that these microstrategies are more specific and thorough; they are more than other translation strategies; and can also show the degree of creativity applied in translation. These microstrategies encompass the following:

1. Direct transfer: a source-text item is copied from the source text and inserted into the target text without making any changes (borrowing).

2. Calque: Transfers the structure or makes a very close translation.

3. Direct translation: Translates in a word-for-word procedure.

4. Explicitation: Makes implicit information explicit.

5. Condensation: Translates in a shorter way, which may involve implication (making explicit information implicit).

6. Deletion: Leaves out a unit of meaning.

7. Addition: Adds a unit of meaning.

8. Paraphrase: Translates rather freely but the meaning of the source text is still present in the target text.

9. Adaptation: the translator adapts the text to the TT audience and culture (recreation).

10. Permutation: Translates the effect in a different place in the text.

11. Substitution: the semantic meaning and the content of the source text item are changed in the target text.

12. Transposition: It refers to any change in word class, for example adjective to noun.

13. Modulation Variation through change of viewpoint and very often of category of thought.

In this study only the creative microstrategies of Schjoldager's model are selected. The justification is given by Chiara Grassill (2014) in which he states that "a common misunderstanding is that translation is a very straightforward process with very little input from the translator. In effect, that the translator is merely a conduit through which one language is transformed into another. However, nothing could be further from the truth. A skilled translator injects a healthy dose of creativity into their task. The act of translating and the creative process are virtually inseparable". In addition, Gui (1995) considers that translation is fundamentally creative for a number of reasons:

1. Translation cannot merely transform an original text into a literal one, but must successfully convey the overall meaning of the original, including that text's surrounding cultural significance.

2. Translators have to form source text ideas into the structure of the target language.

3. The process of searching out a target language counterpart to a difficult source language word or phrase is often creative.

With that being said, the microstrategies of Direct transfer, Calque and Direct translation are not considered creative as they transfer the text very closely and, therefore, they are not included in the investigation.

In order to make this study on microstrategies more detailed and applicable to my analysis, the researcher has added the microstrategy of "Transposition" which is lacking in the original list of microstrategies outlined by Schjoldager (2008). From the researcher's experience as an instructor in translation, "Transposition" may very well be one of the most applied microstrategies in students' translation work.

\section{Statement of the problem}

Translation is not just replacing a textual material in one language with an equivalent textual material in another language. It involves much more than that in terms of its purposes and the tools used. Hence, the same text can have several different translations, some of which can be viewed as creative while others are not, depending on the strategies used. Translation students in the Department of English at Bahrain University have studied a variety of translation courses, however, their level of performance in terms of the processes and the strategies employed while translating news texts has never been examined 
.This study will attempt to examine the creative microstrategies employed by graduating translation students and compare them with those employed by a professional translator working for Bahrain News Agency (BNA).

\section{Research questions}

This study seeks to answer the following questions:

1. Is there a difference between graduating translation students and a professional translator in the use of creative microstrategies?

2. Is there a difference between female and male translation students in the use of creative microstrategies compared with a professional translator?

3. Is there a difference between upper level and lower level translation students in the use of creative microstrategies compared with a professional translator?

\section{Research objectives}

Based on the above, the study aims to achieve the following objectives:

1. To empirically investigate graduating translation students' use of creative microstrategies compared with a professional translator.

2. To find out whether there are any differences between female and male students in the use of microstrategies compared with a professional translator.

3. To explore whether there are any differences between upper and lower level students in the use of microstrategies compared with a professional translator.

\section{Significance of the study}

It is hoped that this study will shed some light on how graduating translation students are employing microstrategies in the process of translating news texts. The findings are expected to provide some insights into the extent of students' use of creative translation strategies. In addition, it will have some positive implications for the teaching and learning of these translation microstrategies as a whole in the Department of English, given the fact that there is a scarcity in the kind of studies such as the present one conducted on Bahraini university students.

\section{Review of literature}

Nugroho (2013) examined Schjoldager's microstrategies of translation as used by undergraduate students of English studies at Dian Nuswantoro University. In order to get the data, a translation task was applied in this study. Twenty native Indonesian students consisting of 13 females and 7 males were involved in the translation task. In addition, 9 students had a GPA of 2.75 or above and 11 students had a GPA below 2.75. All of the students were in their 4th semester and the translation task was conducted during Translation II subject. The study showed that students used only six microstrategies in their translation i.e. direct transfer, direct translation, explicitation, paraphrase, addition, and deletion. It concluded that students who achieved the GPA below 2.75 were creative in translating the text, and male students were more creative than female students.

Atari (2005) conducted an empirical study on the strategies employed by a sample of undergraduate Saudi translator trainees while translating. The study used the think-aloud protocol (i.e. the subjects' verbal reports of what's going on in their heads while translating) as a technique for soliciting the data. The researcher found that the strategies of ST and TT monitoring at the word or sentence level arewere employed most frequently (i.e. language-based strategies). Other important strategies, namely text contextualization and inferencing and reasoning were the least frequently used (i.e. knowledge-based strategies).

The microstrategies employed by two visually impaired translators in translating English texts into Indonesian was investigated by Nogruho et al (2016). Six microstrategies were used by the two subjects in the study, namely, direct transfer, direct translation, explicitation, paraphrase, addition, and deletion. The result interestingly revealed that the visually impaired translator with better English proficiency and with translation training was less creative than the other translator with less proficiency and training.

A study on the strategies employed to translate American humor subtitles of "The Simpsons Movie" into Persian by Amirian, Zahra and Dameneh, Salma (2014) revealed that the most frequently used strategy was "transfer" and the least frequently used strategies were "decimation", "deletion", "imitation", "resignation" and "substitution".

Using a qualitative approach, Adnin (2014) conducted a study examining the translation strategies found in the EnglishIndonesian short story Some Words with a Mummy. The author classified the translation strategies into three kinds, i.e 
syntactic strategies, semantic strategies, and pragmatic strategies. The study revealed that the most frequently used type of translation strategies was the semantic strategies, followed by the pragmatic strategies and the least employed were the syntactic strategies. The reasons given for using the microstrategies in the story were the following: the semantic strategies would make the short story clearly understandable to the target language reader; the pragmatic strategies would make the target language understand the author's purpose, and the syntactic strategies would make the story more natural for reading.

The present study is different from the reviewed studies in that it examines only the creative microstrategies employed by Bahrain University students in the translation of a news text. Then student translations were compared with that of the same news text translated by a professional translator from Bahrain News Agency, which published the translation on its official website.

\section{Methodology}

\subsection{Participants}

The participants in the study were a selected sample of 15 translation students in the Department of English Language \& Literature at Bahrain University. Eleven of them were females (73.3\%) and 4 males (26.6\%), and all were in their early 20 s. At the time of conducting the study, they were all in their final semester of their study before graduating.

\subsection{Instruments and procedure}

An Arabic news text was presented to students for translation. It consisted of five paragraphs, which were already translated by a professional translator from Bahrain News Agency (BNA) and published on its official website. In addition, students were divided into two levels. Upper level (10 students) with a GPA of 2.80 or above (upper level) and students with a GPA below 2.80 ( 5 students). The students were further divided into male students (4 students) and female students (11 students). The Students were asked to translate into English the news text during class time. During the translation process, students were allowed to use offline or online dictionaries and web search engines. The target text of the students' translation work and that of the professional translator were examined and the microstrategies were identified and classified into the various creative microstrategies proposed by Schjoldager (2008) in addition to "Transposition" which was borrowed from Vinay \& Darbenet (1958/2000). In terms of the level of creativity, the microstrategies were divided into more creative and less creative depending on the degree of the change in the semantics of the source of the source text and meanings added to the target text that are not inferred from the source text (Holst: 7-8). Based on Holst's classification, substitution, adaptation, paraphrase, permutation, and addition, are considered more creative, whereas deletion, condensation and explicitation are less creative. "Transposition" is also considered a less creative microstrategy.

\section{Results and discussion}

Table 2 : Microstrategies used by the professional translator in the translation of the news text

\begin{tabular}{llll}
\hline $\mathbf{S} . \mathbf{N}$ & Type of microstrategy & $\mathbf{N}=$ & Percentage \\
\hline 1 & Explicitation & 2 & $3.5 \%$ \\
\hline 2 & Condensation & 1 & $1.7 \%$ \\
\hline 3 & Deletion & 12 & $21.4 \%$ \\
\hline 4 & Addition & 16 & $28.5 \%$ \\
\hline 5 & Paraphrase & 1 & $1.7 \%$ \\
\hline 6 & Adaptation & - & - \\
\hline 7 & Permutation & - & - \\
\hline 8 & Substitution & 21 & $37.5 \%$ \\
\hline Frequency & Transposition & 3 & $5.3 \%$ \\
\hline
\end{tabular}

Table (2) above shows clearly that the most frequently used microstrategies by the professional translator were "Substitution" (37.5\%), followed by Addition (28.5\%), and "Deletion" (21.4\%). The least used microstrategies were "condensation and "Paraphrase", which were used once (1.7\%). From the result we can see that the translator's choice of highly creative microstrategies such as 'substitution' and 'addition' where the meaning changes indicates that the professional translator employs a deeper analysis of the source text when searching for a solution to translation problem. 
Table 3: Microstrategies used by ALL students

Microstrategy

\begin{tabular}{|c|c|c|c|c|c|c|c|c|c|}
\hline Microstrategy & 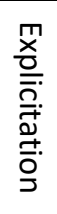 & 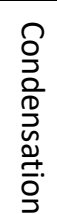 & $\begin{array}{l}\text { D } \\
\frac{\mathbb{D}}{\mathbb{D}} \\
\stackrel{+}{0} \\
\frac{0}{D}\end{array}$ & $\begin{array}{l}\frac{1}{2} \\
\frac{2}{2} \\
\frac{0}{1} \\
\frac{1}{1}\end{array}$ & 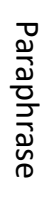 & 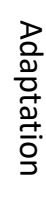 & 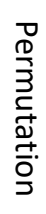 & 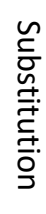 & 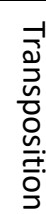 \\
\hline
\end{tabular}

\begin{tabular}{|c|c|c|c|c|c|c|c|c|c|c|}
\hline \multirow[t]{15}{*}{ No. of Microstrategies } & 1 & - & 2 & 1 & - & - & - & 4 & 4 & \\
\hline & - & - & - & - & 1 & - & - & - & 9 & \\
\hline & - & - & - & 2 & - & - & - & 7 & 13 & \\
\hline & - & - & - & 1 & 1 & - & - & 1 & 8 & \\
\hline & 1 & - & - & 3 & - & - & - & 6 & 4 & \\
\hline & - & - & 3 & 1 & - & - & - & 4 & 9 & \\
\hline & - & - & - & 1 & - & - & - & 3 & 8 & \\
\hline & 1 & - & 2 & 1 & - & - & - & 16 & 9 & \\
\hline & - & - & - & - & - & - & - & 1 & 6 & \\
\hline & - & - & 1 & 1 & 2 & - & - & 1 & 9 & \\
\hline & - & - & 1 & 1 & - & - & - & 7 & 7 & \\
\hline & - & - & 1 & 2 & - & - & - & 2 & 6 & \\
\hline & - & - & - & - & - & - & - & 8 & 7 & \\
\hline & - & - & - & 4 & 3 & - & - & - & 5 & \\
\hline & 2 & 1 & 1 & 2 & - & - & - & 7 & 7 & \\
\hline Total & 5 & 1 & 11 & 20 & 7 & - & - & 67 & 111 & $=222$ \\
\hline Percentage & $2.2 \%$ & $0.4 \%$ & $4.9 \%$ & $9 \%$ & $3.1 \%$ & - & - & $30 \%$ & $50 \%$ & $=100 \%$ \\
\hline
\end{tabular}

Table (3) reveals that students in general have a tendency to use "transposition" microstrategy in their translation as $50 \%$ have opted for it in their translation. The second highest percentage in the students' translation is "substitution", which represented $30 \%$ of all uses of microstrategies. This is followed by "addition" (9\%). The explanation for this is that 'transposition' is a syntactic strategy and thus does not require much effort in rendering the source language item into the target language. On the other hand, using "substitution, which is a semantic microstrategy, and "addition" which is a pragmatic microstrategy required students to perform some cognitive analysis to the source language item and, therefore, had lower percentages.

Table 4: Microstrategies used by all students compared to the professional translator

\begin{tabular}{|c|c|c|c|c|c|c|c|c|c|}
\hline & Microstrategy & 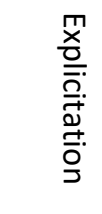 & 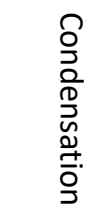 & $\begin{array}{l}\frac{D}{D} \\
\frac{D}{D} \\
\stackrel{D}{+} \\
\frac{0}{J}\end{array}$ & $\begin{array}{l}\frac{1}{2} \\
\frac{2}{2} \\
\frac{0}{1} \\
\frac{0}{3}\end{array}$ & 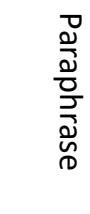 & 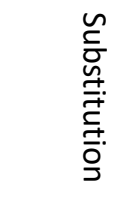 & 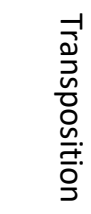 & \\
\hline \multirow{2}{*}{ 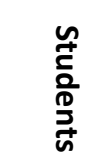 } & $\begin{array}{l}\text { No. of } \\
\text { Microstrategies }\end{array}$ & 5 & 1 & 11 & 20 & 7 & 67 & 111 & 222 \\
\hline & Percentage & $2.2 \%$ & $0.4 \%$ & $4.9 \%$ & $9 \%$ & $3.1 \%$ & $30 \%$ & $50 \%$ & $100 \%$ \\
\hline \multirow{2}{*}{ 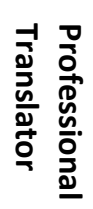 } & $\begin{array}{l}\text { No. of } \\
\text { Microstrategies }\end{array}$ & 2 & 1 & 12 & 16 & 1 & 21 & 3 & 56 \\
\hline & Percentage & $3.5 \%$ & $1.7 \%$ & $21.4 \%$ & $\begin{array}{l}28.5 \\
\%\end{array}$ & $1.7 \%$ & $37.5 \%$ & $5.3 \%$ & $100 \%$ \\
\hline
\end{tabular}


Table (4) compares all students' use of microstrategies with the professional translator. The table shows clearly that the professional translator has a very low percentage of the syntactic microstrategy of "transposition" (5.3\%) whereas the students have the highest percentage (50\%). In addition, it shows the professional translator focuses more on the semantic and pragmatic strategies where he has a higher percentage of "Addition" (28.5\%) and Deletion (21.4\%). Students, on the hand, have low percentages on the same microstrategies (9\%) and (4.9\%) respectively. This indicates that much more cognitive analysis has been performed by the professional translator, compared with that of the students. The only students' microstrategy with a high percentage is the semantic microstrategy of "substitution" (30\%), which is close to that of the professional translator (37\%). This indicates that students have made an effort to carry out some cognitive analysis of the text.

Table 5: Microstrategies used by MALE students Microstrategy

\begin{tabular}{|c|c|c|c|c|c|c|c|c|c|c|}
\hline Students & 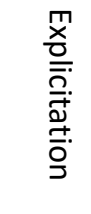 & 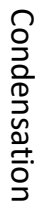 & 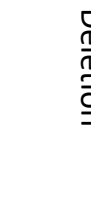 & & & $\begin{array}{l}\frac{0}{0} \\
\frac{0}{2} \\
\frac{0}{2} \\
\frac{0}{0} \\
\text { D }\end{array}$ & $\begin{array}{l}\frac{7}{2} \\
\frac{0}{0} \\
\frac{0}{0} \\
\frac{d}{0} \\
\frac{1}{0} \\
\frac{0}{7}\end{array}$ & $\begin{array}{l}\frac{0}{10} \\
\frac{D}{3} \\
3 \\
\frac{1}{0} \\
\frac{0}{0} \\
\frac{0}{2}\end{array}$ & 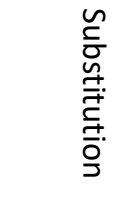 & 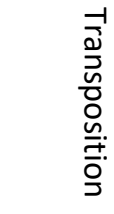 \\
\hline 1 & 1 & - & 2 & 1 & - & & - & - & 4 & 4 \\
\hline 2 & - & - & - & - & 1 & & - & - & - & 9 \\
\hline 3 & - & - & - & 2 & - & & - & - & 7 & 13 \\
\hline 4 & - & - & - & 1 & 1 & & - & - & 1 & 8 \\
\hline Total & 1 & - & 2 & 4 & 2 & & - & - & 12 & 34 \\
\hline Percentage & $1.8 \%$ & - & $3.6 \%$ & $7.2 \%$ & $3.6 \%$ & & - & & $21.8 \%$ & $61.8 \%$ \\
\hline
\end{tabular}

Table (5) shows that male students have a high percentage (61.8\%) of the syntactic microstrategy of "transposition", followed by the semantic one "substitution" (21.8\%). However, they have low percentages of the pragmatic microstrategies of "Explicitation" (1.8\%), "Deletion" (2\%) and "Addition" (7.2\%). This indicates that male students seem to focus more on the structure of the source text in order to avoid committing errors resulting from analyzing the text.

Table 6: Microstrategies used by FEMALE students Microstrategies

\begin{tabular}{|c|c|c|c|c|c|c|c|c|c|}
\hline Students & 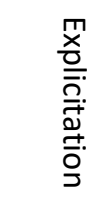 & 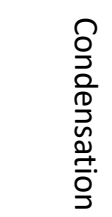 & $\begin{array}{l}\frac{7}{0} \\
\frac{D}{0} \\
\stackrel{0}{0} \\
\frac{0}{1}\end{array}$ & $\begin{array}{l}\frac{8}{2} \\
\frac{0}{\overline{0}} \\
\frac{0}{2}\end{array}$ & 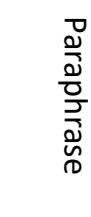 & 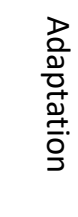 & 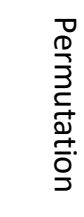 & 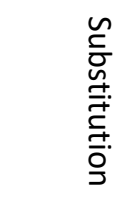 & $\begin{array}{l}\overline{\overline{0}} \\
\overline{\bar{v}} \\
\bar{c} \\
\bar{g} \\
\bar{v} \\
\bar{c}\end{array}$ \\
\hline 1 & 1 & - & - & 3 & - & - & - & 6 & 4 \\
\hline 2 & - & - & 2 & 1 & - & - & - & 4 & 9 \\
\hline 3 & - & - & - & 1 & - & - & - & 3 & 8 \\
\hline 4 & 1 & - & 2 & 1 & - & - & - & 16 & 9 \\
\hline 5 & - & - & - & - & - & - & - & 1 & 6 \\
\hline 6 & - & - & 1 & 1 & 2 & - & - & 1 & 9 \\
\hline 7 & - & - & 1 & 1 & - & - & - & 7 & 7 \\
\hline 8 & - & - & 1 & 2 & - & - & - & 2 & 6 \\
\hline 9 & - & - & - & - & - & - & - & 8 & 7 \\
\hline 10 & - & - & - & 4 & 3 & - & - & - & 5 \\
\hline 11 & 2 & 1 & 1 & 2 & - & - & - & 7 & 7 \\
\hline Total & 4 & 1 & 8 & 16 & 5 & - & - & 55 & 77 \\
\hline Percentage & $2.4 \%$ & $0.6 \%$ & $4.8 \%$ & $9.6 \%$ & $3.0 \%$ & - & - & $33.1 \%$ & $46.3 \%$ \\
\hline
\end{tabular}


Table (6) shows that the highest percentage for female students is in the use of the "Transposition" microstrategy (46.3\%), followed by "Substitution" (33.1\%). A small percentage below (10\%) was calculated for the rest of the microstrategies. The result indicates an inclination by female students towards the syntactic analysis with a lesser degree towards the semantic and the pragmatic one.

Table 7: Microstrategies used by Male, Female students compared to the Professional Translator

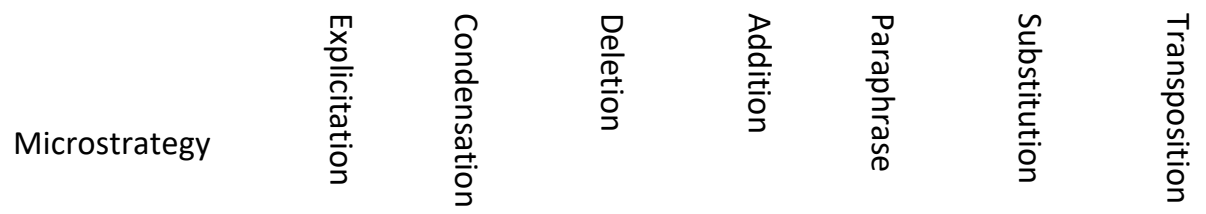

\begin{tabular}{|c|c|c|c|c|c|c|c|c|c|c|}
\hline \multirow{3}{*}{$\begin{array}{l}\text { Female } \\
\text { Students }\end{array}$} & No. of & 4 & 1 & 8 & 16 & 5 & 55 & 77 & $=$ & 166 \\
\hline & Microstrategies & & & & & & & & & \\
\hline & Percentage & $2.4 \%$ & $0.6 \%$ & $4.8 \%$ & $9.6 \%$ & $3.0 \%$ & $33.1 \%$ & $46.3 \%$ & $=$ & $100 \%$ \\
\hline \multirow{3}{*}{$\begin{array}{l}\text { Male } \\
\text { Students }\end{array}$} & No. of & 1 & - & 2 & 4 & 2 & 12 & 34 & $=$ & 55 \\
\hline & Microstrategies & & & & & & & & & \\
\hline & Percentage & $1.8 \%$ & - & $3.6 \%$ & $7.2 \%$ & $3.6 \%$ & $21.8 \%$ & $61.8 \%$ & $=$ & $100 \%$ \\
\hline \multirow[t]{2}{*}{$\begin{array}{l}\text { Professional } \\
\text { translator }\end{array}$} & $\begin{array}{l}\text { No. of } \\
\text { Microstrategies }\end{array}$ & 2 & 1 & 12 & 16 & 1 & 21 & 3 & $=$ & 56 \\
\hline & Percentage & $3.5 \%$ & $1.7 \%$ & $21.4 \%$ & $28.5 \%$ & $1.7 \%$ & $37.5 \%$ & $5.3 \%$ & $=$ & $100 \%$ \\
\hline
\end{tabular}

Table (7) above shows that male students have the highest percentage (61\%) in their use of the less creative syntactic "Transposition" microstrategy, while female students come second with (46.3\%). The professional translator has the least use of this syntactic microstrategy (5.3\%). The table reveals that the more creative semantic microstrategy of "Substitution" is also relatively high among both female and male students; however, female students have a higher percentage of (33\%) which is closer to that of the professional translator (37.5\%). This is an indication that female students are more creative than male students. The professional translator has a higher percentage than both male and female students in all other microstrategies. It is clear that the professional translator, compared with male and female students used a higher number of semantic and pragmatic microstrategies of "Addition", "Deletion", "Substitution" and less of the syntactic microstrategy of "transposition". Surprisingly, both male and female students used a higher number of the more creative semantic "paraphrase" microstrategy than that of the professional translator. This is perhaps due to the fact that "paraphrasing", compared with the other more creative microstrategies, deals with the same meaning in the process of change rather than adding, deleting or substituting which requires a more complex level of cognitive analysis.

Generally speaking, we can say that female and male students are closer to the professional translator in only $28.5 \%$ in each of their use of the more and the less creative microstrategies.

Table 8: Microstrategies used by Upper Level compared to Lower Level Students

\begin{tabular}{|c|c|c|c|c|c|c|c|c|c|c|}
\hline $\begin{array}{l}\text { Student } \\
\text { Level }\end{array}$ & Microstrategy & $\begin{array}{l}\text { r } \\
\frac{x}{\bar{n}} \\
\overline{\bar{a}} \\
\overline{0} \\
\overline{0}\end{array}$ & 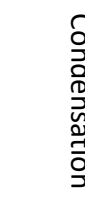 & & & 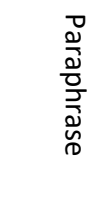 & $u$ & $=$ & & \\
\hline \multirow[t]{2}{*}{$\begin{array}{l}\text { Upper } \\
\text { Level }\end{array}$} & $\begin{array}{l}\text { No. of } \\
\text { Microstrategies }\end{array}$ & 3 & 1 & 8 & 14 & 6 & 41 & 81 & $=$ & 154 \\
\hline & Percentage & $1.9 \%$ & $0.6 \%$ & $5.1 \%$ & $9.0 \%$ & $3.8 \%$ & $26.6 \%$ & $52.5 \%$ & $=$ & $100 \%$ \\
\hline \multirow{2}{*}{$\begin{array}{l}\text { Lower } \\
\text { Level }\end{array}$} & No. of & 2 & - & 3 & 5 & 1 & 26 & 30 & $=$ & 67 \\
\hline & $\begin{array}{l}\text { Microstrategies } \\
\text { Percentage }\end{array}$ & $2.9 \%$ & - & $4.4 \%$ & $7.4 \%$ & $1.4 \%$ & $38.8 \%$ & $44.7 \%$ & $=$ & $100 \%$ \\
\hline
\end{tabular}


Table (8) indicates that upper level students have a higher percentage (52.5\%) than lower level students (44.7\%) in their use of the less creative syntactic microstrategy of "Transposition" and a lower percentage in the more creative semantic microstrategy of "Substitution" (26.6\%). This is an interesting result since high achievers are expected to use a higher level of cognitive analysis of the text. As far as other microstrategies are concerned, the difference between both levels have close percentages. Generally, the result indicates that the upper level focuses more on the less creative syntactic microstrategy than the lower level students who appear to carry out a higher level of cognitive analysis as they had a higher percentage of the more creative semantic "Substitution" microstrategy. As for the other microstrategies, there is only a small difference between them in the less and more creative strategies.

Table 9: Microstrategies used by Upper and Lower Level students compared to the Professional Translator

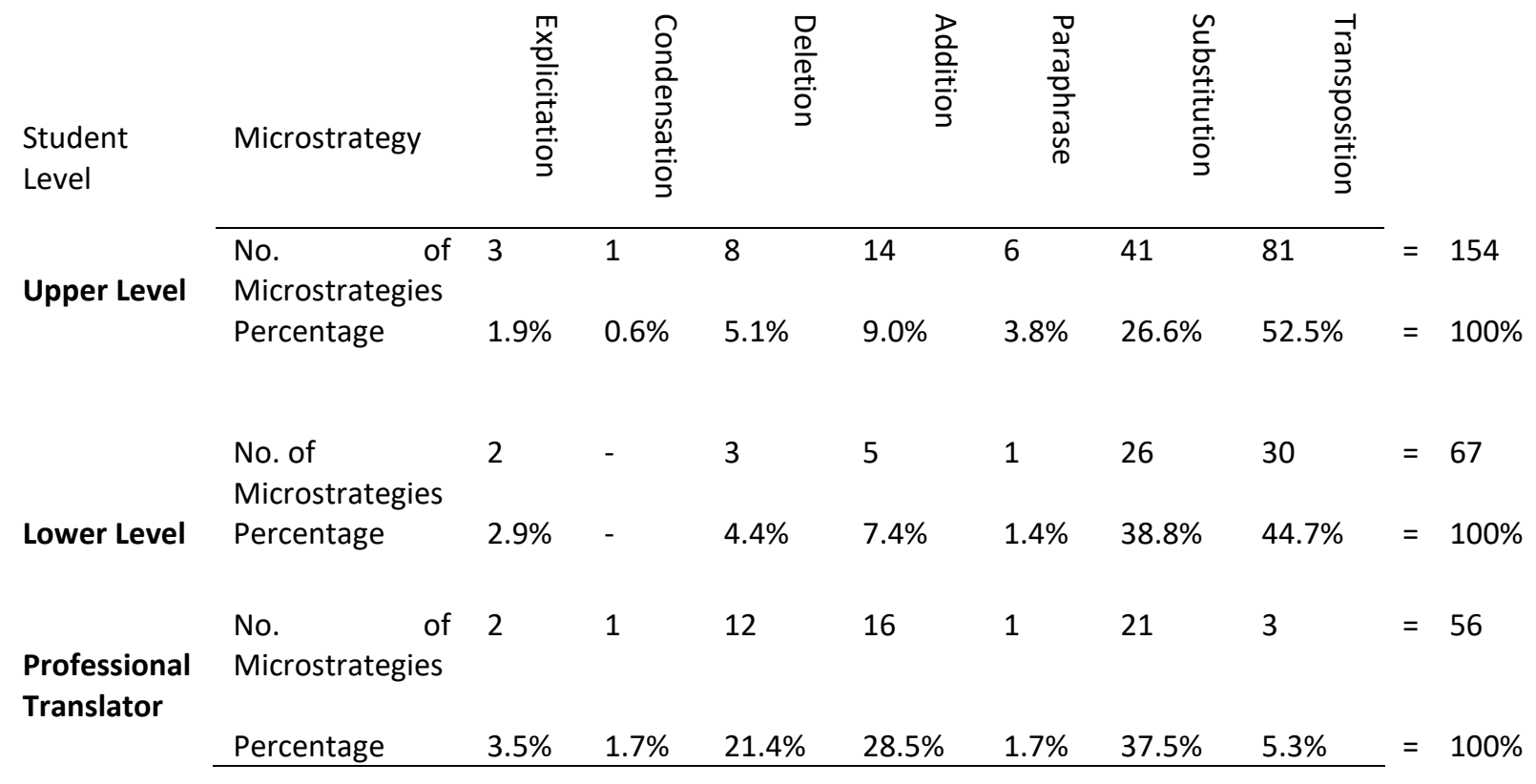

Table (9) shows that both levels of students had a smaller percentage of the less creative microstrategies of "Explicitation $(1.9 \%)-(2.9 \%)$ and "condensation" $(0.6 \%)-(0 \%)$ than the professional translator (3.5\%) - (1.7\%) respectively. As for the more creative microstrategies, the professional translator has a higher percentage of use than both levels of students except for "paraphrase" where the upper level students have a slightly higher percentage $(3.8 \%)$ than the lower level students $(1.4 \%)$ and the professional translator (1.7\%). The table reveals that upper level and lower levels of students opt for the less creative syntactic microstrategy of "Transposition" with their high percentage of use $(52 \%-44.7 \%)$ respectively compared with a small percentage of the professional translator (5.3\%). Concerning the more creative semantic and pragmatic microstrategies of "Addition", "Substitution" and" Deletion", the professional translator has a higher percentage than both levels of students, which indicates that he uses a deeper analysis than the students of both levels. The upper level students, however, have a higher percentage than both the professional translator and the lower level students in using the semantic more creative microstrategy of "paraphrase" which indicates students made an effort to perform some kind of cognitive analysis.

In general, we can say that compared to the professional translator, upper level students are almost similar in $75 \%$ of their use of the less creative microstrategies and slightly over $50 \%$ in the more creative microstrategies.

Lower level students are almost $50 \%$ similar to the professional translator in their use of the less creative microstrategies and almost $50 \%$ similar with regard to the more creative microstrategies.

\section{Conclusion}

Based on the preceding discussion and analysis of the data, it is clear that translation students in the study are generally inclined to focus more on the syntactic and structural dimensions rather than on the semantic and pragmatic ones when processing and rendering the source texts into the target language. Both levels of Students appear to have focused on the syntactic structure compared with the professional translator. Interestingly, the lower level, compared with the upper level 
students, have shown more creativity by carrying out some kind of cognitive analysis. Female students, despite their high percentage of the less creative syntactic microstrategy, were more creative than male students and were somewhat closer to the professional translator in using the most creative microstrategy of "substitution", which requires a higher and more complex level of analysis. The result has indicated that high achievers in English language in general does not mean that they are also high achievers in translation. As the result has shown, creativity in translation is more than knowledge in language but requires a deeper discourse analysis of the text.

Generally speaking, Unlike the professional translator, students' lack of negotiation with and deeper analysis of the text has deprived their performance from the creativity required for the translation of texts such as the journalistic one and thus, would render it, to a certain extent, into a mechanical exercise. This can be attributed mainly to students' fear of producing any change when processing the source text and thus adhere to literal translation.

In terms of pedagogy, translation instructors must focus on the process-oriented work that takes into account the mental processes and transformations embedded within the act of translation. The findings of the paper point to the following:

Firstly, Classroom teaching must involve and encourage students in deeper analysis and more change in the source text beyond the syntactic structure. Secondly, while the product in translation is important, the mental processes involved in the act of translation are of equal importance. Thirdly, there should be more exercises with texts that require students to use a variety of creative microstrategies such as addition and substitution, which transcend semantic meanings into the pragmatic ones. Fourthly, students should be taught that they must free themselves from the hegemony of the source text and that the change, novelty and originality in translation is not "treason" after all!

This paper has dealt only with the use of translation microstrategies in one type of texts i.e. a news text; therefore, in order to complete the picture of students' performance in translation, further research is required to investigate students' use of these creative microstrategies in other types of texts.

\section{References}

[1] Adnin, A. N. (2014). An Analysis of Translation Strategies Found in English-bahasa Indonesia Short Story Some Words with a Mummy. Jurnal Ilmiah Mahasiswa Fakultas Ilmu Budaya Universitas Brawijaya. https://www.neliti.com/publications/205094/an-analysis-oftranslation-strategies-found-in-english-bahasa-indonesia-short-st

[2] Amirian, Z., \& Dameneh, S. (2014). Microstrategies Employed for Translation of English Humor Subtitled into Persian: A Case Study of The Simpsons Movie. Journal of Intercultural Communication, (34). http://immi.se/intercultural.

[3] Atari, O. (2005). Saudi Students' Translation Strategies in an Undergraduate Translator Training Program. Meta. 50 (1), pp. $180-193$. https://www.erudit.org/fr/revues/meta/2005-v50-n1-meta864/010667ar/

[4] Baker, M. (1992). In other words: A course book on translation. London: Routledge.

[5] Bell, R. T. (1991). Translation and translating: Theory and practice. London and New York: Longman.

[6] Bell, R. T. (1998). Psychological/cognitive approaches. In M. Baker (Ed.). Routledge encyclopedia of translation studies. London \& New York: Routledge.

[7] Dorri, E. R. (2018). On the Study of Creativity in Translation: the Case study of a Journalistic Text. https://translationjournal.net/July2018/on-the-study-of-creativity-in-translation-the-case-study-of-journalistic-text.html

[8] Holst, J. ( 2010). Creativity in Translation - A Study of Various Sources and Target Texts. Institut for Sprog og Erhvervskommunikation: Aarhus School of Business.

[9] House, J. (1997). Translation Quality Assessment: a Model Revised. Tübingen: Gunter Narr Verlag. http://blackflagwingchun.weebly.com/history.html.

[10] Jääskeläinen. J. (1993). Investigating Translation Strategies. Tirkkonen-Condit, S., \& Laffling, J. (eds.), Recent Trends in Empirical Translation Research (Studies in Languages. Joensuu: University of Joensuu.

[11] Jensen, Matilde Nisbeth. (2009) Professional Translators' Establishment of Skopos - A Brief' Study. Institut for Sprog og Erhvervskommunikation: Aarhus School of Business.

[12] Loescher, W. (1991). Translation performance, translation process and translation strategies. Tuebingen: Guten Narr.

[13] Lorscher, W. (1996). A psycho linguistic analysis of translation processes. Meta , 41 (1), pp.26-32. http://erudit.org/revue/meta/2004/v41/n1/029689ar.html.

[14] Newmark, P. (1988a). A Textbook of Translation. Hertfordshire: Prentice Hall.

[15] Newmark, P. (1988b). Approaches to Translation. Hertfordshire: Prentice Hall.

[16] Nida, E. A. (1964). Towards a science of translation, with special reference to principles and procedures involved in Bible translating. Leiden: Brill.

[17] Nord, C. (2005). Text analysis in translation. Theory, methodology, and didactic application of a model for Translation-Oriented Textual Analysis. Second edition. Amsterdam/New York: Rodopi

[18] Nugroho, R. A. (2013). The Use of Microstrategies in Students' Translation: A Study on Classroom Translation Process and Product. UNS Journal of Language Studies. 1(2), 
[19] Nugroho, R. , Nababan, M.,\& Subroto, M. (2016). Translation Microstrategies Used by Visually Impaired Translators. International Journal of English Linguistics, 6 (5).

[20] Schjoldager, A. (2008). Understanding Translation. Aarhus: Academica

[21] Venuti, L.. (1998). Strategies of translation. In M. Baker (Ed.), Encyclopedia of translation studies (pp. 240-244). London and New York: Routledge.

[22] Venuti, L. (2000). The translation studies reader. London and New York: Routledge.

[23] Vinay, J., \& Darbelnet, J. (1995). Comparative stylistics of French and English. Amsterdam: Benjamins.

[24] Seguinot, C. (1989). The translation process. Toronto: H.G. Publications. 